\title{
A hazai közúti közlekedési hálózatot terhelő forgalom elemzése
}

\author{
Az OCM-2016 projekt keretében elkészült forgalmi modell lehe- \\ tőséget biztosít arra, hogy a közúthálózat forgalmát ne csak az \\ adott keresztmetszeten áthaladó forgalom nagysága, hanem an- \\ nak célja és eredete alapján is elemezzüi.
}

DOI 10.24228/KTSZ.2017.5.7

\section{Miksztai Péter - Virág Álmos - Bozó András}

E-mail: miksztai.peter@kti.hu, virag.almos@kti.hu, bozo.andras@kti.hu

\section{BEVEZETÖ}

A közúti közlekedési hálózat forgalmi terhelését egyik oldalról megítélhetjük a többé-kevésbé rendszeresen elvégzett keresztmetszeti forgalomszámlálások eredményei alapján, amelyek a teljes országra adnak valamilyen (mért vagy számított) értéket. Másik oldalról viszont önmagában a keresztmetszeti forgalomnagyságok semmilyen információt nem adnak arról, hogy az adott helyen áthaladó forgalom honnan jön és hová tart, milyen mélyebb rétegzettségü, márpedig a jármüvek viselkedésének megértéséhez, valamint a jövőbeli fejlesztések, illetve forgalomnagyság-változások hatásainak elemzéséhez ez mindenképpen szükséges. Ezt a célt a honnan-hová forgalomáramlási mátrixok létrehozásával, majd számítógépes modellben történő hálózati ráterheléssel érhetjük el. Az OCM-2016 projekt keretében elkészült forgalmi modell célja a nyers mátrixok helyességének ellenőrzése, kalibrálása volt. Az így elkészült modell lehetőséget adott az adatok széles körü elemzésére is.

\section{MÓDSZERTAN}

A területi modell 1722 forgalmi körzetből állt, amely elsősorban a járások területének tovább-bontásából épült fel, de kialakítottunk lakosszámmal nem rendelkező, valamint külföldi körzeteket is. A kisebb településeket egy csoportba vontuk, és ezek együtt képeznek egy forgalmi körzetet, a közepes méretű települések (jellemzően kisvárosi kategória) önállóan alkotnak egy-egy forgalmi körzetet, míg a nagyobb városok (jellemzően a megyeszékhelyek és nagyvárosok) pedig több forgalmi körzetre lettek bontva. Ilyen körzetekböl összesen 1556 szerepel a modellben. Ezeken kívül létrehoztunk olyan, lakosszámmal nem rendelkezö, mégis koncentrált forgalomvonzó vagy -kibocsátó tulajdonságokkal rendelkező zónákat, amelyeket ipari-kereskedelmi-logisztikai körzeteknek nevezhetünk. E körzettípusból 86-ot definiáltunk az országban. Mivel a Magyarország közútjait terhelő forgalom egy része külföldről származik, külföldi forgalmi körzeteket is kialakítottunk, amelyeknek mérete az országhatár közelében viszonylag kicsi volt, de az országtól távolodva azokat egyre nagyobb méretünek határoztuk meg, hiszen minél távolabbról érkezik a forgalom, annál kevésbé kell az elemzések szempontjából a helyváltoztatás kiinduló és végpontjának földrajzilag pontosnak lennie. Külföldi körzetből 80-at definiáltunk a modellben.

A belföldi közúthálózati modell alapját az Országos Közúti Adatbank (OKA) képezte. Az OKA állományából a modellezési feladatunknak megfelelő mezők kerültek leválogatásra a teljes országra vonatkozóan. A föbb jellemzők a következők voltak: útszám, útkategória, sávszám, szakaszjelleg (kül-/belterület), szakaszhossz, terepjelleg, súlykorlátozás, sebességkor- 
látozás, útdíj van/nincs. Az OKA által tárolt térképi állományból generáltunk egy szakadásmentes, modellezhető hálózatot, amelynek létrehozása, konvertálása, ellenőrzése számottevő kézi munkát is szükségessé tett. A külföldi úthálózatot publikusan elérhető térinformatikai térképi állományokból generáltuk, azonban ez esetben csak az útkategória és a sávszám volt a modellezéshez fontos paraméter.

A modellezést az EMME szoftver segítségével végeztük. A modellhálózat csomópontokból és az azokat összekötő, irányított szakaszokból áll. Fontos körülmény, hogy a szoftver képes kezelni az útgeometriát, tehát a hálózat alakhelyes lesz, nem csupán egyenesekkel lehet összekötni a modellcsomópontokat. A felépített hálózat így mintegy 18500 csomópontból és 45000 élből (szakaszból) áll. Ebbe beleértendőek azok a hálózatrészek is, amelyeket az OKA nem tartalmaz, de a modellezéshez szükségesek, mint pl. Budapest úthálózata, egyéb települések hálózati jelentőségü, helyi útjai, illetve a külföldi úthálózat legfontosabb elemei.
A forgalom ráterhelése során a járművek megengedett össztömege alapján megkülönböztetett öt mátrixot használtunk. Ezek az alábbiak: személygépkocsik, kistehergépkocsik 3,5 tonnáig, majd a 3,5-7,5 t közötti tehergépkocsik, a 7,5-12 t közötti tehergépkocsik, végül a $12 \mathrm{t}$ feletti tehergépkocsik. A ráterhelés során a különböző járműkategóriákat külön rétegként terheltük rá, mégpedig olyan sorrendben, hogy elsőként a 12 t engedélyezett össztömeg feletti tehergépkocsikat, azután a 7,5-12 t közöttieket, majd a 7,5 t alattiakat. Ezt követte a kistehergépkocsik mátrixa, végül a személygépkocsik mátrixa került ráterhelésre. Ez azt jelenti, hogy mindegyik réteg az előtte levőt már mint „alapterhelés” érzékelte, és annak tudatában választott útvonalat, hogy azok már ott közlekednek. Az elsőként használt nyers mátrixok a közúthálózatra terhelve még nem adják vissza kellő pontossággal és megbízhatósággal a mért forgalomnagyságokat, így szükség volt kalibrálásra, azaz a mátrixoknak a mért értékekhez való igazítására. Ehhez az

\section{1. ábra: A kalibrált mátrixok ráterhelési ábrája}

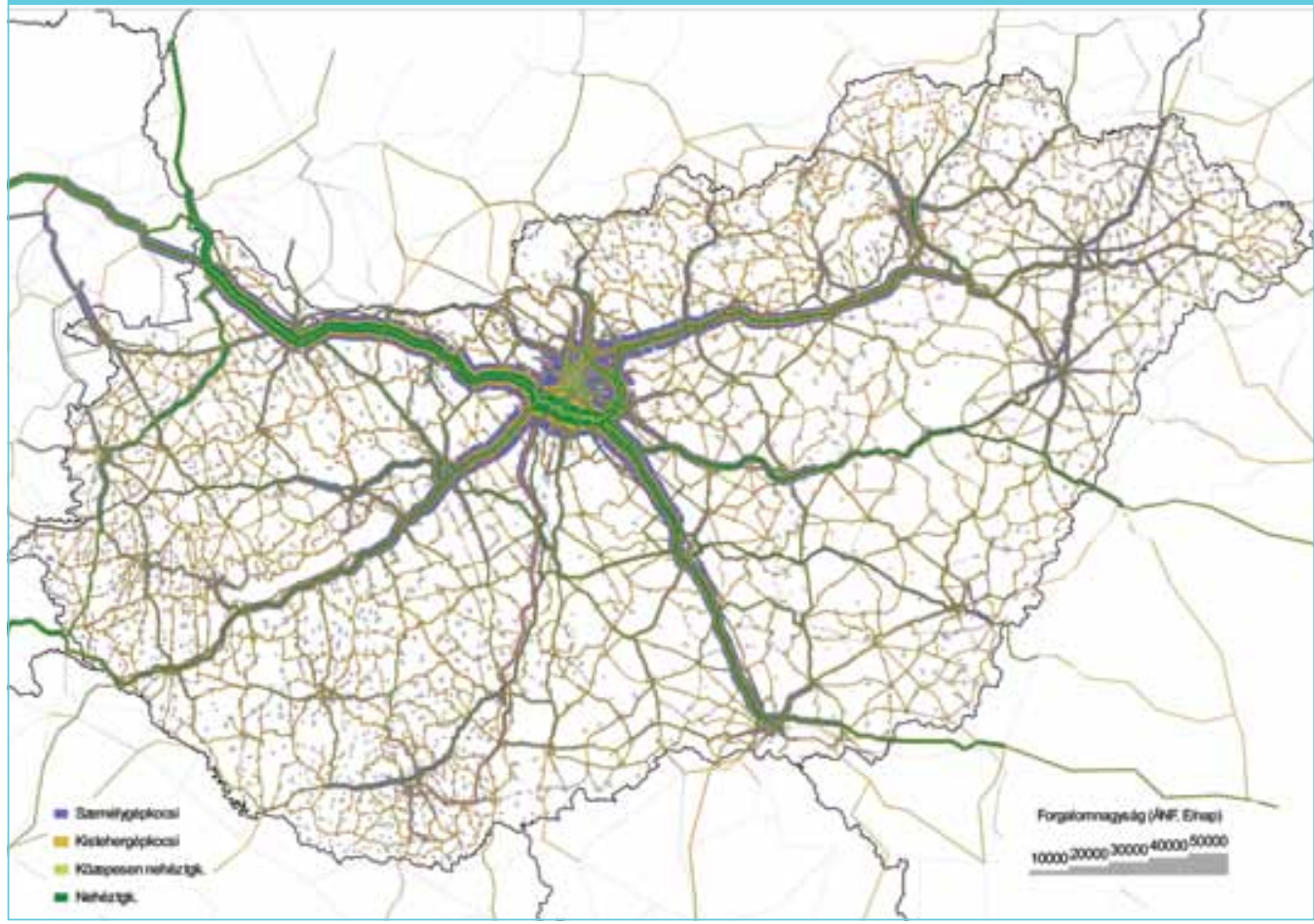


országos közúthálózat külsőségi szakaszain 324 keresztmetszetet jelöltünk ki. A kalibráló forgalomnagyságok többsége a Magyar Közút $(\mathrm{MK})$ Zrt. adataiból, kisebb része pedig a Nemzeti Útdíjfizetési Szolgáltató (NÚSZ) Zrt. adatfelvételeiből származott. A kalibrált mátrixok hálózatra való ráterhelésének eredményeit mutatja be az 1 . ábra.

\section{A KÖZÚTHÁLÓZAT KAPACITÁS- KIHASZNÁLTSÁGA}

A közúti forgalmi ráterhelések kettős célt szolgáltak. Egyrészt a jelen állapotban ezzel az eszközzel élve végeztük el a mátrixok kalibrálását, másrészt a távlati állapotokban ezekre támaszkodva vizsgáltuk a hálózaton, illetve a Magyarországot átszelő folyosókban megjelenő forgalom nagyságát és ennek viszonyát az ott rendelkezésre álló kapacitáshoz, illetve az eltürhető forgalomnagyság elméleti értékéhez. Az ÚT 2-1.201 számú Útügyi Müszaki Előírás (KTSZ) rendelkezik a forgalmi tervezés során alkalmazandó, az eltűrhető szolgáltatási szinthez tartozó forgalomnagyságokról. Tekintettel arra, hogy az OCM-2016 mátrixaiban helyközi forgalmak szerepelnek, tehát nem tartalmazzák a településeken belül lebonyolódó helyi forgalmakat (amelyek a település méretének növekedésével egyre jelentősebbek), a vizsgálataink során nem elemezzük a belterületi szakaszok kapacitáskihasználtságát, hanem csak a külterületi szakaszok forgalomnagyságait vetjük össze az eltűrhető szolgáltatási szinthez tartozó forgalomnagyságokkal, melyet a 2 . ábra mutat be. A szemléletesebb ábrázolás érdekében $a z$ egyes kategóriák színnel és szélességgel is meg vannak különböztetve egymástól.

Látható, hogy a legterheltebb utak jellemzően Budapest közvetlen közelében vannak. Az M0 autóút forgalma a déli szektorban, a Duna-híd magasságában eléri, kissé meg is haladja az eltürhető szintet. Az M0 több csomópontjának közelében is hasonló a helyzet. Az M1-M7 autópályák bevezető szakaszának, illetve a 11. sz. foúútnak az

\section{2. ábra: Forgalomnagyság az eltürhető szolgáltatási szinthez tartozó értékhez viszonyítva}

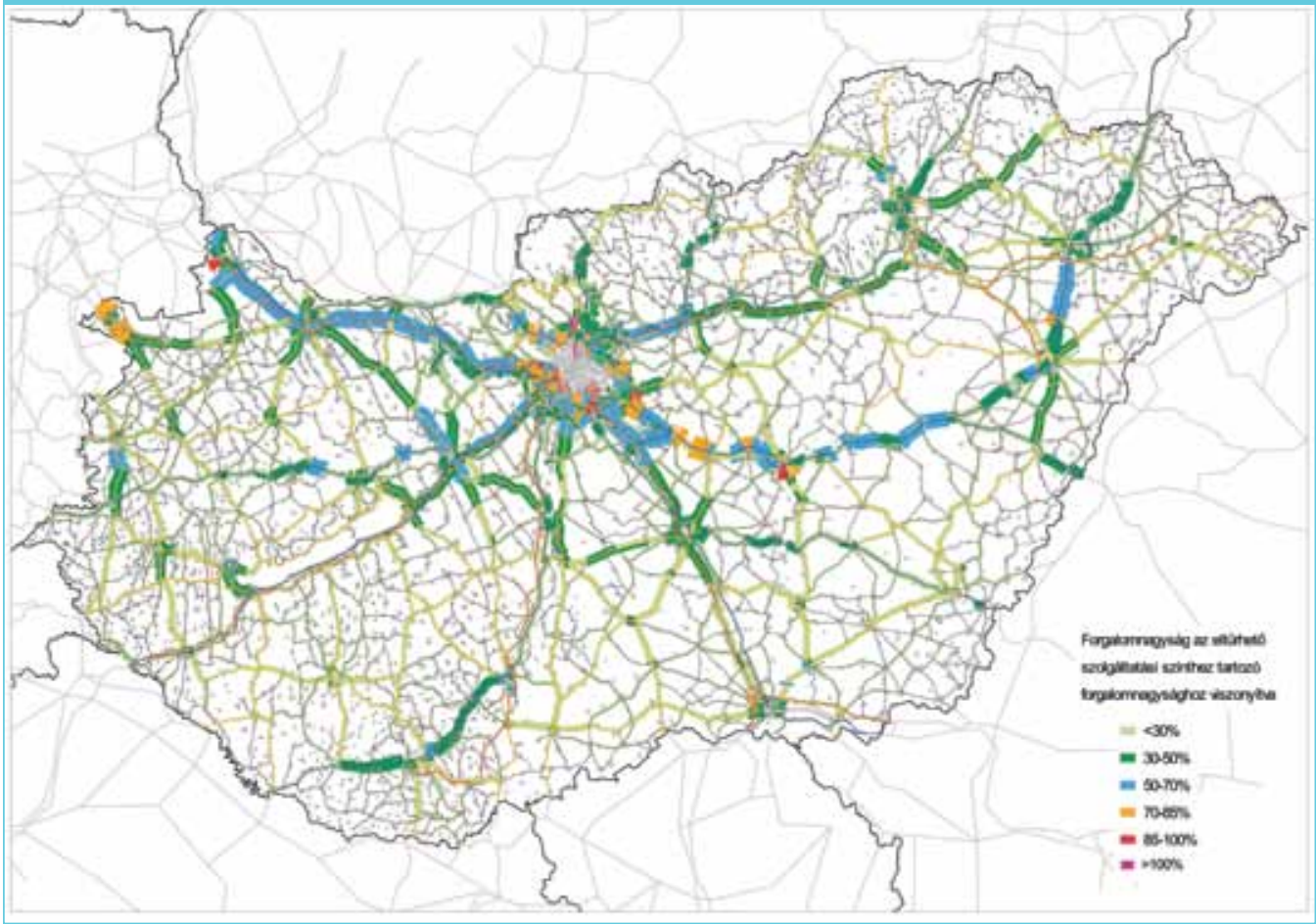


M0 környékén mérhető forgalma bőven az eltürhető szint felett van. Távolabb haladva a fövárostól már nemigen találunk olyan utat, ahol a forgalomnagyság meghaladná az eltürhető szintet, de például a 4 . sz. fóút szolnoki elkerülő szakasza megközelíti azt.

Több olyan szakaszt is találhatunk, ahol a forgalomnagyság az eltürhető szint $85 \%$-a (tehát nagyjából a „még megfelelö” szint) környékén, vagy kissé alatta van. Ilyen pl. a 84. sz. foút Sopron közelében, a 10. sz. foút Budapest és Piliscsaba között, az M1 autópálya Herceghalom és Biatorbágy térségében, de az M0 autóut több szakasza is ide sorolható. A 4. sz. foút hosszabb szakaszon minősíthető terheltnek, Üllő és Monor térségében, valamint Albertirsa és Cegléd között (a négysávos szakaszok kivételével) az eltűrhető szint $75-80 \%$-án állnak. (Ez is alátámasztja az épülö M4 gyorsforgalmi út szükségességét.)

A 70\%-os szint alatt több utat is találhatunk. Ez még mindig jelentős forgalomra utal, még ha nem is igényel azonnali beavatkozást. Az autópályák közül ide sorolható az M1 Herceghalomtól az M15-ig, az M7 Érdtől Székesfehérvárig (csak ebben az irányban, hiszen Budapest felé 3 sáv van), az M5 az M0-tól nagyjából Újhartyán, Örkény magasságáig, valamint az M3 Gödöllőtől Hatvanig terjedő szakasza. Ugyanakkor megjegyezhető, hogy az M7 autópálya a szezonális ingadozásból adódóan a nyári hónapokban rendkívül terhelt, meghaladja az eltürhető szintet, az itt vizsgált érték az éves átlagra érvényes. A 10. sz. foút és a 4 . sz. föút már említésre került a zsúfoltabb utak között. Amely szakaszuk oda nem tartozik, azok itt szerepelhetnek (pl. a 4. sz. föút jelentős része Cegléd és Püspökladány vagy Debrecen és Nyíregyháza között). A 405. sz. föút szinte teljes hosszában ide sorolható, az 51. sz. fóút az M0-tól Majosháza, Délegyháza vonaláig szintén, sőt itt egy rövid szakaszon $90 \%$ fölé szökik a szóban forgó mutató.

50 és 60\% között találhatunk még néhány főúti szakaszt, mint pl. a 81. sz. főút Székesfehérvár és Mór között vagy a 63. sz. fóut Székesfehérvár közelében egy rövid szakaszon, de a 86. sz. föút Szombathely térségében, nagyjából Kisunyomig szintén ide sorolható. De nemcsak föutakon találkozhatunk ilyen számokkal, mert például a 8102. j. út Budakeszi és az M1 autópálya között $60 \%$ körüli értéket mutat. Az M0 déli szektorában több, az autóutra rávezető négy számjegyü út is hasonló arányokkal rendelkezik.

\section{SZEMÉLYGÉPJÁRMÜ-FORGALOM}

Amennyiben kizárólag a személygépkocsi-forgalom nagyságát vizsgáljuk, az 1 . ábrára tekintve azonnal feltünhet Budapest gazdasági és társadalmi túlsúlya az ország térszerkezetében. Ennek köszönhetően a gyorsforgalmi utak zöme a fövárosból indul (vagy, ha úgy tetszik, oda érkezik) és a személygépkocsi-forgalom az agglomerációhoz közeledve folyamatosan növekszik. Ezt a következtetést lehet levonni akkor is, ha megvizsgáljuk azokat a belföldi utazási relációkat, amelyeket a legnagyobb személygépkocsi-forgalom jellemez. Budapest és az agglomeráció települései között lényegesen nagyobb forgalom generálódik, mint az ország más települései között.

Az ország úthálózatán a belföldi forgalom mellett természetesen a tranzitforgalom is megjelenik. A határt kétszer átlépő autósok elsősorban a gyorsforgalmi utakon közlekednek. A 2008-as adatfelvételünk óta eltelt közel 10 év gyorsforgalmi úthálózatot érintő infrastruktúra-fejlesztései elsősorban a tranzitforgalmat érintették. 2008. augusztusban adták át az M70 autóutat, amellyel az akkori modell csak korlátozottan tudott számolni, valamint 2015. júliusban az M43 autópályát is teljes hosszban használatba lehetett venni. A 2008-as adatfelvétel konklúziói között megállapítást nyert, hogy a Románia-Németország és Románia-Olaszország relációban figyelhető meg a legnagyobb tranzitforgalom, valamint jelentős, kétszeres határátlépő forgalom jellemzi az osztrák határszakaszt a Burgenland-Sopron-KópházaBurgenland viszonylatban.

A legfrissebb adatokra épülő ráterhelés azt mutatja, hogy ezek az áramlási irányok az elmúlt évtizedben nem változtak. Továbbra is jelentős a belépő, átutazó forgalom Arad irányából, amely most Csanádpalotánál lépi át a határt, és az M43 autópályán halad tovább az M5 irányába. Az itt közlekedő, mintegy 1000 személygépkocsi 40\%-a hagyja el hazánkat Hegyeshalom- 
nál és Tornyiszentmiklósnál az M5-M0-M1 gyorsforgalmi utakon Ausztria, Németország (Nyugat-Európa), valamint az M5-M0-M7M70 gyorsforgalmi utakon, elsősorban Olaszország irányában átszelve az országot, illetve ezekből az irányokból tart Románia felé. Az is megállapítható, hogy a nagylaki határátkelő 2008-as forgalmának másfélszerese mérhető együttesen a 43. sz. foúton és az M43 autópályán, aminek kétharmada az autópályán közlekedik. Ekkora forgalom terelődött át tehát a két éve átadott autópályára. Az M1-M0-M5 közlekedési folyosó tranzitforgalmának másik jelentős részét az országba Röszkénél belépő és Hegyeshalomnál kilépő személygépkocsik adják (3. ábra). Ennek a forgalomnak a nagyságát jelentősen befolyásolják a Nyugat-Európában dolgozó vendégmunkások szezonális utazásai. Ennek alátámasztására 2016. augusztus 28-án, szombaton kiegészítő forgalomszámlálást (és célforgalmi kikérdezést) végeztünk a röszkei átkelőnél. A felmérés eredménye rámutatott arra, hogy az átlagos őszi hétköznapi forgalom nagyságát több mint 70\%-kal meghaladja az augusztus végén mért forgalom nagysága, melynek $85 \%$-át a tranzitforgalom tette ki. ${ }^{1}$

A 2008-ban megfigyelt burgenlandi/bécsi kiindulópontú és végcélú utazások továbbra is markánsan - napi mintegy 500-600 személygépkocsis nagyságrendben - megjelennek a hazánkat érintő tranzitforgalomban. Ezen utazások jellemzően Bécsben kezdődnek, és a soproni, majd a kópházai határátkelőhelyen keresztül Burgenlandban végződnek, vagy a Soprontól délre elhelyezkedő és a Fertő tótól keletre található burgenlandi települések között generálódnak. További apró érdekesség, hogy a tornyosnémeti határátkelö esetében megjelenik egy kismértékü, mintegy 7\% arányú tranzitforgalom, amely Komárom és Tornyosnémeti között használja a magyar közutakat a Kelet-Szlovákiából Nyugat-Szlovákiába történő eljutás érdekében.

A tranzitforgalom mellett érdemes szót ejteni a szomszédos országokba irányuló személygép-

\section{3. ábra: A röszkei határátkelőhelyen áthaladó személygépkocsi-forgalom nagysága és iránya}

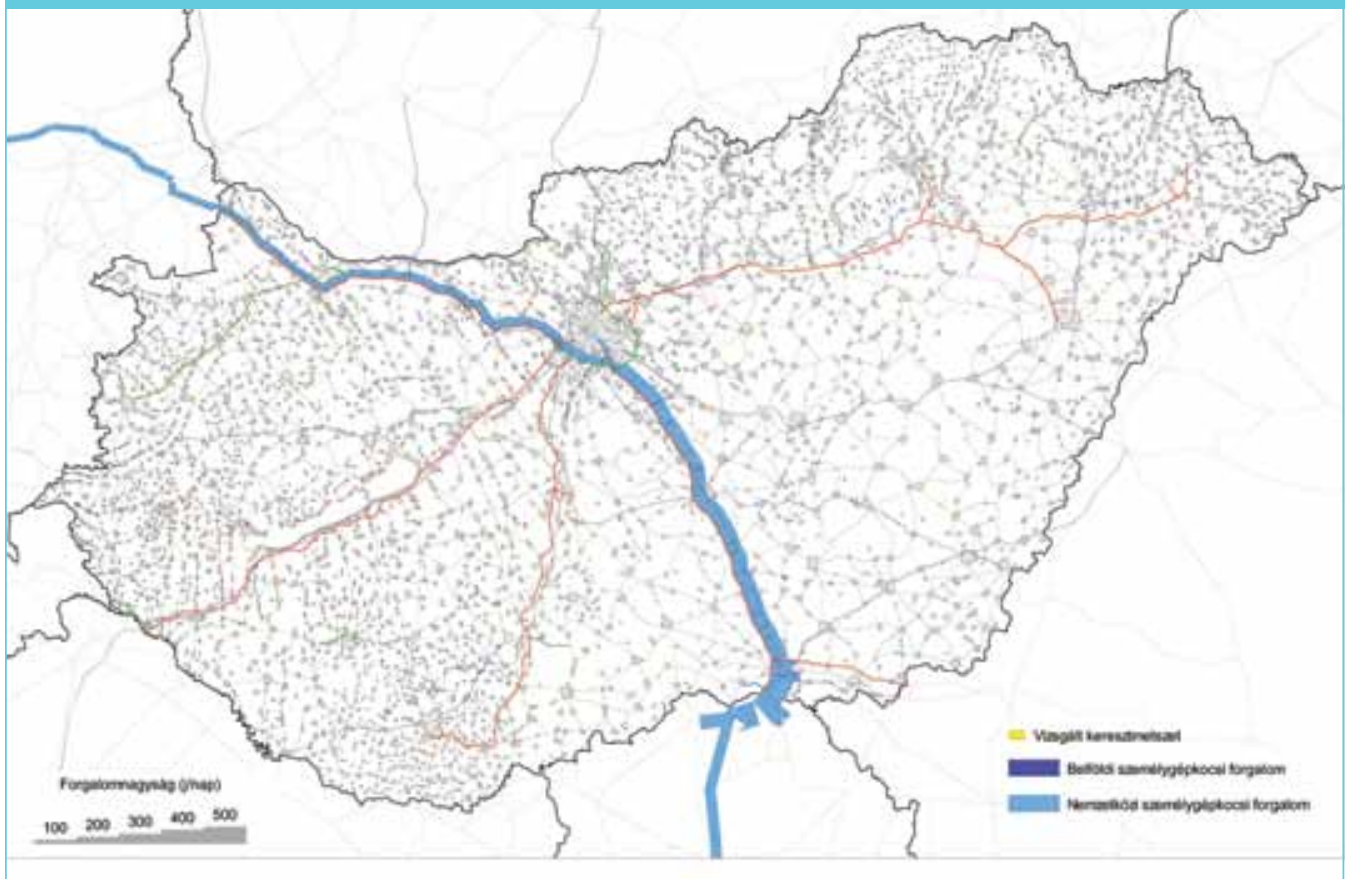

${ }^{1}$ A kikérdezett autósok 75\%-a Törökországból, Szerbiából és Bulgáriából indult, és 44\%-uk Németországba, 14\%-uk Ausztriába tartott. 
kocsi-forgalomról is. Legfontosabb és legforgalmasabb határátkelőnk, Hegyeshalom bonyolítja az úti cél szempontjából legheterogénebb forgalmat. A forgalmi rangsorban Hegyeshalmot követő Komárom, Sopron és Esztergom elsősorban szomszédos forgalmat bonyolít, a tranzitutazások száma ezeken a határátkelőkön elenyésző. Összességében a magyar-osztrák határszakaszon lényegesen több személygépkocsi kel át egy nap, mint a többi határszakaszon.

\section{TEHERGÉPJÁRMÜ-FORGALOM}

A Magyarországot érintő teherforgalmi elemzés során a 3,5-7,5 t, valamint a 7,5 t engedélyezett össztömeg fölötti járműkategóriák mind belföldi, mind nemzetközi és tranzitútjait tekintettük át, és ezeket egységesen tehergépkocsi-forgalom néven vizsgáltuk. Bár az egyes kategóriákat itt összevontan kezeltük, a teljes képhez hozzátartozik, hogy a nemzetközi közúti áruszállítás mintegy 90\%-ban 12 t feletti engedélyezett össztömegű nehéz tehergépkocsikkal történik.
A Magyarország határát átlépő közúti áruszállítás - azaz a nemzetközi forgalom -, valamint a Magyarország határain belül lebonyolódó közúti áruszállítás - azaz a belföldi forgalom eltérő mértékben terheli a hazai közúthálózatot. Egyes szakaszokon a nemzetközi fuvarok alkotják a forgalom döntő többségét, míg máshol a belföldi forgalom dominál, de elöfordulnak olyan szakaszok is, ahol a két halmaz elemei közel azonos arányban vannak jelen. A fenti csoportosítás nem kifejezetten utakra, hanem útszakaszokra vonatkozik, mivel egy-egy út különböző szakaszai különböző csoportokba tartozhatnak.

A nemzetközi forgalom két domináns iránya közül az egyik a kelet-nyugati áramlás, amely Románia és a nyugati országok között zajlik, a másik pedig az észak-déli, amely Lengyelország, Csehország, Szlovákia és Szlovénia, Olaszország között áramlik. A 4. ábrán is jól kivehető, hogy míg Románia felől elsősorban az M43/43. sz. és 42. sz., kisebb mértékben a 44. sz.

\section{4. ábra: A Magyarországot érintő nemzetközi közúti teherforgalom nagysága}

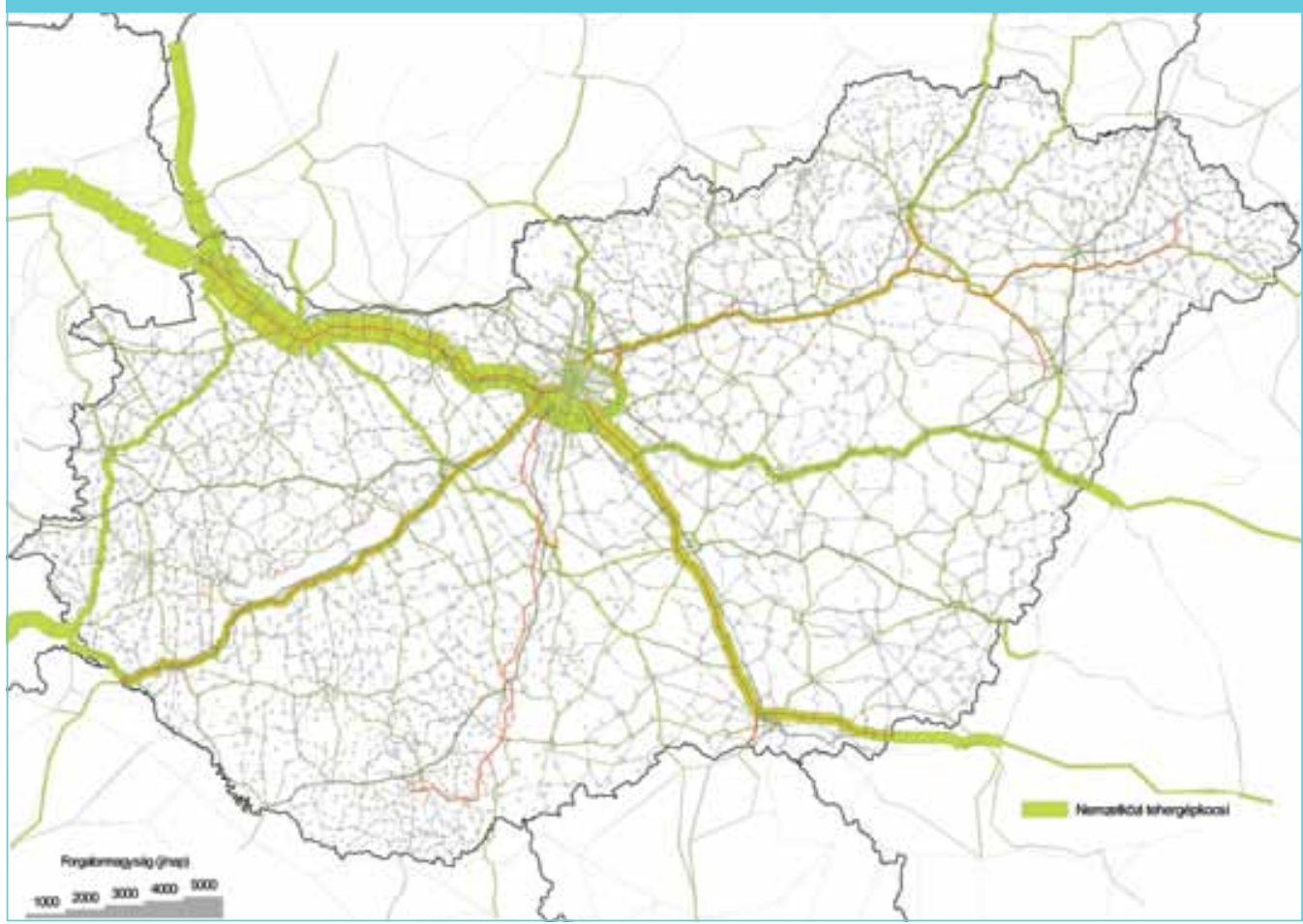


főtakon áramlik a forgalom, a nyugati határszélen már az M1 és M15, illetve délnyugaton az M70 gyorsforgalmi út jelenti a kapcsolódási vonalakat. Az észak-déli áramlást illetően a nyugati határszélen az M15 és a M86/86. sz. utak biztosítják az osztrák A2-es autópályát elkerülő „menekülőutat” Szlovénia és Olaszország felé.

Ezt támasztja alá az a tény is, hogy a NÚSZ által eladott viszonylati jegyek közül a Rajka-Rédics útvonal az egyik legnagyobb számban értékesített tranzitutazásra jogosító viszonylati jegy.

Az első csoport elemeire, azaz ahol a nemzetközi forgalom van túlsúlyban, remek példa többek között az M86 autóút Répcelaknál (5. ábra), ahol a nemzetközi tehergépkocsi-forgalom az összes tehergépkocsi-forgalomnak a 2/3-a. Az itt áthaladó nemzetközi szállítások kapcsolódó határátkelőhelyei Rajka és Rédics. Persze sok más útszakaszon is elöfordul, hogy a nemzetközi fuvarok a belföldihez képest többségben vannak (például az M7 Fonyód- nál, vagy az M1 Tatabányánál), a fenti példa a kifejezetten nemzetközi utazások kiszolgálását hivatott TEN-T hálózat elemein gyakori.

A második körbe tartozó útszakaszoknál jellemzően a belföldi forgalom van túlsúlyban. Ilyen például a 4. sz. főút Hajdúszoboszlónál és Ceglédnél, az M3 Hatvannál, illetve Mezőkövesdnél és az M5 Kiskunfélegyházánál. Az ebbe a csoportba tartozó útszakaszok között az egyik érdekesség, hogy a TEN-T átfogó hálózat részét képező majdani M8 gyorsforgalmi utat jelenleg helyettesítő 8 . sz. fóúton Herendnél, illetve az 52. sz. föúton Fülöpházánál (6. ábra) a belföldi forgalom az összes tehergépkocsi forgalom 2/3-a. A másik érdekesség a napi 19500 tehergépkocsi forgalmát lebonyolító M0 déli szektora, ahol a rendkívül erős nemzetközi forgalmat is felül tudja múlni a Budapest miatt pezsgő belföldi forgalom. Elsősorban nagyvárosok közelében jellemző az a tendencia, hogy a belföldi fuvarok aránya megnő az adott úton.

\section{5. ábra: Az M86 autóuton Répcelaknál áthaladó teherforgalom aránya és iránya}

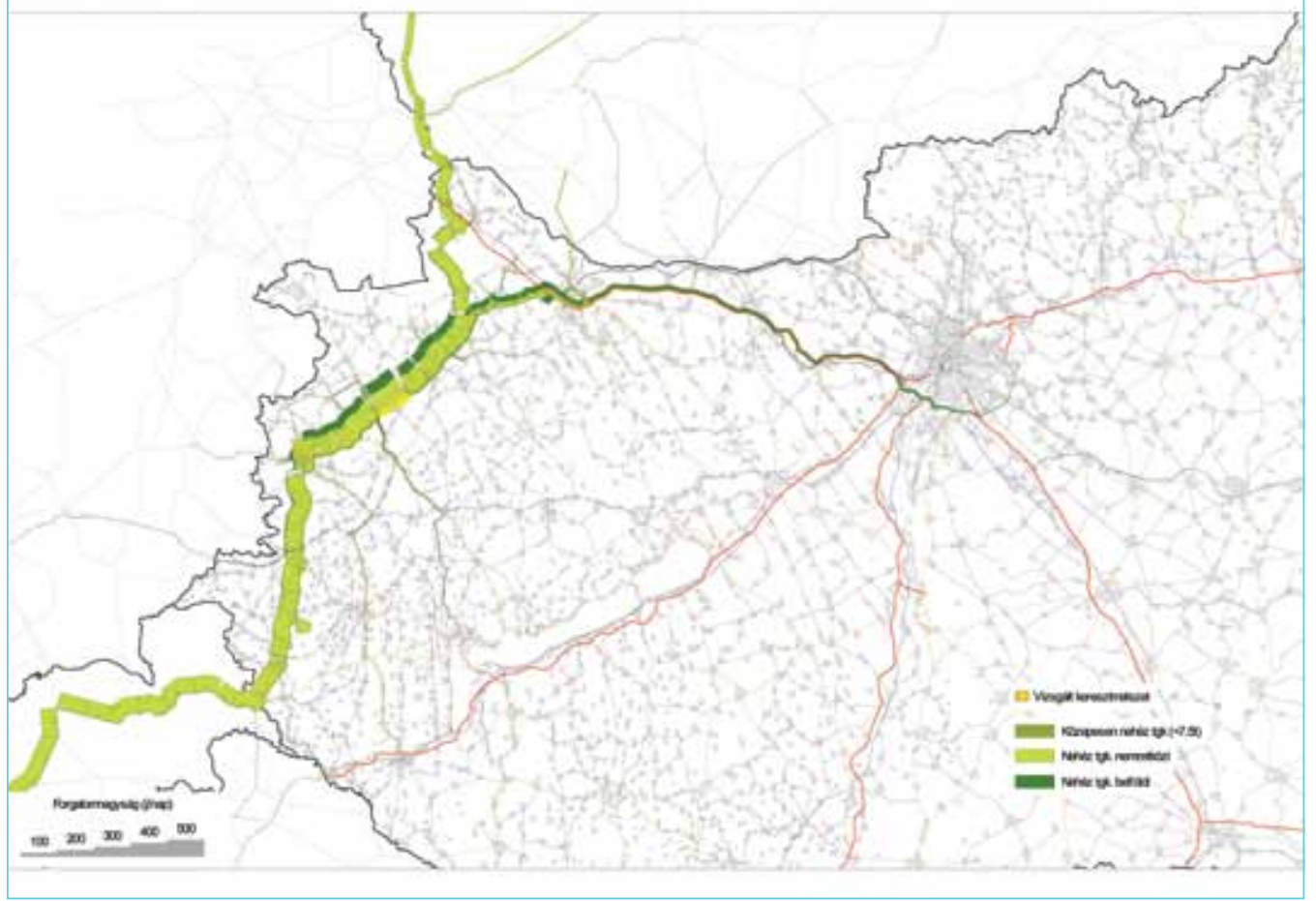


A harmadik halmazba végül olyan útszakaszok kerültek, ahol a nemzetközi és a belföldi forgalom közel azonos mértékben van jelen. Ilyen például a 405 . sz. foút (7. ábra), ahol nagyságrendileg napi 3000 tehergépkocsi halad át, amelynek fele nemzetközi viszonylatban közlekedik. Az itt bonyolódó nemzetközi utazások kapcsolódási pontjai nyugaton Rajka, Hegyeshalom és Tornyiszentmiklós, míg keleten Ártánd határátkelője.



A korábban már részletezett, az utak terhelését leíró százalékos telítettségi mutatók értelmezéséhez fontos azt is szem elött tartani, hogy a jelenleg $2 \times 1$ sávos útszakaszok közül némelyiken kiemelkedően magas a tehergépkocsiforgalom mértéke. Ilyenek a 4 . sz. és 42 . sz.,

\section{7. ábra: A 405. sz. foúton áthaladó közúti teherforgalom aránya és iránya}

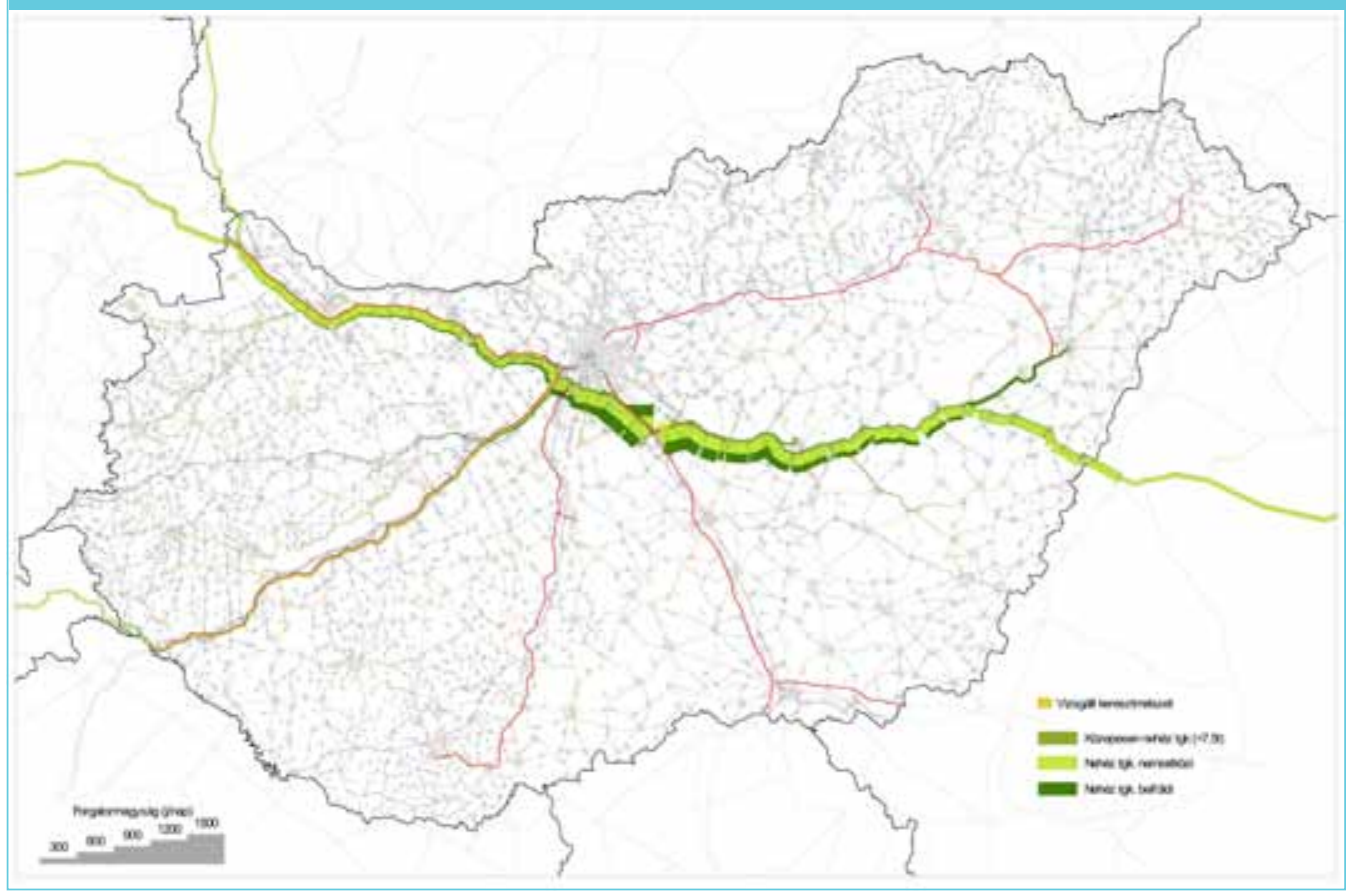


valamint a 44. sz. főutak, amelyek a Románia és Németország, illetve Olaszország között áramló forgalom egy részét vezetik le, továbbá az M15 és a 86. sz. főút $2 \times 1$ sávos szakaszai, amelyeken az északi országok és Szlovénia, illetve Olaszország közötti forgalom zajlik, továbbá az M70 autóút terhelésének döntő többsége, ahol még $2 \times 1$ sávon halad a forgalom.

\section{6. ÖSSZEFOGLALÓ}

A forgalmi modell lehetőséget biztosít arra, hogy a közúthálózat forgalmát ne csak az adott keresztmetszeten áthaladó forgalom nagysága, hanem annak célja és eredete

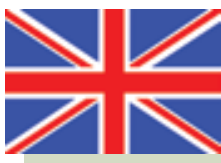

\section{Traffic analysis of the domestic road transport network}

The purpose of the traffic model in the OCM2016 project was to verify and calibrate the correctness of raw matrices, and the model thus prepared gave an opportunity to analyse data in a broader way. Considering the capacity utilization of the road network, it can be stated that the most congested roads are typically close to Budapest. The traffic of the M0 motorway is up to or even slightly over the tolerable level at the Danube Bridge in the southern sector. Similarly, the analysis of passenger car traffic has shown that the traffic between Budapest and its suburbs is significantly higher than between other settlements of the country. The most significant transit traffic can be observed on the M43, M5 and M1 motorways, where the rate of transit traffic increases towards the border crossings. International and domestic road freight traffic burdens the domestic road network differently. In some sections, international freight is the major part of traffic, whereas domestic traffic dominates elsewhere, but there are also sections where the elements of the two sets are in balance. alapján elemezzük. A forgalom nagysága Budapest agglomerációjában a legnagyobb, azonban a kihasználtság alapján országszerte több egyéb út is a jelentős forgalmi terhelést viselők közé tartozik. A személygépkocsi-forgalomról hasonlóak mondhatóak el. Ha a nemzetközi személygépkocsi-forgalom értékeit nézzük, akkor megállapíthatjuk, hogy azok elsősorban a gyorsforgalmi utakra koncentrálódnak, azok közül is kiemelkedik az M1-M0-M5 útvonal. Tehergépkocsik tekintetében több föútvonal is jelentős tranzitforgalmat bonyolít le, miközben más autópályákon alig tapasztalható nemzetközi forgalom.

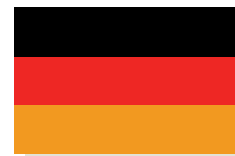

\section{Analyse des einheimischen Straßennetz belastenden Verkehrs}

Der Zweck des im Rahmen des OCM2016-Projektes erstellten Verkehrsmodells war es, die Richtigkeit der Rohmatrizen zu überprüfen und zu kalibrieren, und das so vorbereitete Modell gab eine Möglichkeit für den umfassenden Analyse der Daten. Bei der Untersuchung der Kapazitätsauslastung des Straßennetzes kann festgestellt worden, dass die meist belastete Straßen in der Regel in der unmittelbarer Nähe von Budapest liegen. Die Verkehrsbelastung der Autobahn M0 liegt bis zu oder sogar etwas über dem erträglichen Niveau bei der Donaubrücke im südlichen Sektor. Ebenso bestätigte die Analyse des Pkw-Verkehrs, dass es ein wesentlicher höherer Verkehr zwischen Budapest und der Agglomeration generiert wurde, als es zwischen den anderen Siedlungen des Landes gab. Der bedeutendste Transitverkehr kann auf den Autobahnen M43, M5 und M1 beobachtet werden, wo die Transitverkehrsrate in Richtung der Grenzübergänge zunimmt. Der internationale und der inländische Straßengüterverkehr belastet das inländische Straßennetz unterschiedlich. In einigen Abschnitten nimmt die internationale Fracht der Hauptteil des Verkehrs, während an anderen Stellen der Inlandsverkehr dominiert, aber es gibt auch Abschnitte, in denen die Elemente der beiden Sätze im Gleichgewicht sind. 


\title{
Prof Dr. Holló Péter
}

kutató professzor

KTI Közlekedéstudományi Intézet Non-profit Kft., Közlekedésbiztonsági Központ

\section{Közlekedésbiztonság az Európai Unióban - szakmai beszámoló egy konferenciáról}

\begin{abstract}
Hasznos, ha közvetlenül kapunk információt a nemzetközi tapasztalatokról! A megállapítások és a tendenciák segítenek a hazai törekvések megalapozásában, de fontos az európai jövőkép
\end{abstract} folyamatos figyelemmel kísérése is.

DOI 10.24228/KTSZ.2017.5.8

\section{NÉHÁNY SZÓ A RENDEZVÉNYRÖL}

2017. június 15. és 17. között az olaszországi Bresciában rendezték meg a „Város és infrastruktúra tervezés a biztonság és a városi élet jobb minősége érdekében” címü, XXIII. Nemzetközi Konferenciát, amelynek alcíme „Élet és gyaloglás a városokban” volt.

A kétévente megrendezésre kerülő nemzetközi konferenciára a helyi egyetem (Universitá degli Studi di Brescia) épületeiben került sor.

Dr. Maurizio Tira professzor, a konferencia elnökének meghívására a KTI Közlekedéstudományi Intézet képviselőjeként vettem részt a tudományos bizottság munkájában, szekcióelnökként, illetve vitaindító előadás felkért előadójaként.

Az első plenáris ülés előtt két köszöntő hangzott el, amit Maurizio Tira professzor és Roberto Busi, - aki a konferencia örökös elnöke - tartott.

A plenáris ülésen két vitaindító előadást hallhattunk. Rodney Tolley (Egyesült Királyság) a gyaloglás szerepét méltatta minden szempontból. Élhető, gyalogosbarát, a védtelen közlekedők számára biztonságos városokról beszélt. Kiemelte a gépkocsik megosztásának („car sharing”) fontosságát. A gyaloglás méltatása közben bizonyos fokig persze a kerékpárosokkal szemben foglalt állást („Ne használjuk a kerékpárt a gyalogosok ellen!”). Elmondta, hogy a kerékpárosoknak világszerte erős szervezeteik vannak, míg a gyalogosok esetén ez távolról sincs így. Megemlítette, hogy pl. a kerékpár vonaton történő szállítása sok helyet foglal el a többi utas rovására. Részletezte a gyaloglás egészségügyi és gazdasági előnyeit, kiemelve, hogy az fellendítheti a helyi kereskedelmet. Tolley hangsúlyozta a gyalogosforgalom mérésének jelentőségét is.

Ezt követően Graham Parkhurst (Egyesült Királyság) tartotta meg előadását. Először a globális felmelegedés témájával foglalkozott. Elmondta, hogy az EU-ban a közlekedésből eredő üvegházhatású gázok 23\%-a lakott területekről származik. Ismertette az EU vonatkozó, 35 évre szóló stratégiáját, amelynek két fontos területe a jármüvek hatásfokának javítása, illetve a dekarbonizáció. 